\title{
Detection molecular of Rangelia vitalii in dogs from Parana State, Southern Brazil
}

\author{
Detecção molecular de Rangelia vitalii em cães do Estado do Paraná, Sul do Brasil \\ Bianca Ressetti da Silva ${ }^{1 *}$; Morgana de Fátima Kuteques Ferreira ${ }^{2}$; Gabriela Maffezzolli ${ }^{2}$; Marília de Oliveira Koch ${ }^{1}$; \\ Olair Carlos Beltrame; Isis Indaiara Gonçalves Granjeiro Taques³; Amanda Noéli da Silva Campos³; \\ Daniel Moura de Aguiar ${ }^{3}$; Rosangela Locatelli Dittrich ${ }^{1}$

\begin{abstract}
${ }^{1}$ Programa de Pós-graduação em Ciências Veterinárias, Universidade Federal do Paraná - UFPR, Curitiba, PR, Brasil
${ }^{2}$ Laboratório de Patologia Clínica Veterinária, Hospital Veterinário, Universidade Federal do Paraná - UFPR, Curitiba, PR, Brasil

${ }^{3}$ Laboratório de Virologia e Rickettsioses, Hospital Veterinário, Faculdade de Medicina Veterinária, Universidade Federal de Mato Grosso - UFMT, Cuiabá, MT, Brasil
\end{abstract}

Received September 4, 2018

Accepted October 5, 2018

\begin{abstract}
Rangelia vitalii infects erythrocytes, leukocytes and endothelial cells of dogs. The present study aimed to report the molecular detection confirmed by sequencing of $R$. vitalii in the state of Paraná, as well as describe the clinical, hematological and biochemical alterations of the infected dogs. Three sick dogs from the metropolitan area of Curitiba, PR, Brazil, underwent a physical exam, and laboratory tests included hematology, biochemistry, polymerase chain reaction (PCR), and gene sequencing. Clinical signs included apathy, anorexia, and hemorrhage. Intra-erythrocytic and extracellular piroplasms were found on peripheral blood smears from all three dogs. Blood samples from these animals were positive for Babesia sp. by PCR targeting $18 \mathrm{~S}$ rRNA. PCR products from all three dogs were sequenced, and BLAST analysis showed that the PCR-generated sequences were highly homologous with those of $R$. vitalii previously reported. Hematologic findings included severe anemia, shift of neutrophils to the regenerative left, and thrombocytopenia. Serum urea levels were increased in all three dogs, and direct bilirubin levels were elevated in one dog.
\end{abstract}

Keywords: Dog, hemoparasite, nambiuvú, rangeliosis, tick-borne disease.

\section{Resumo}

Rangelia vitalii infecta eritrócitos, leucócitos e células endoteliais de cães. O presente estudo objetivou relatar a detecção molecular confirmada por sequenciamento de $R$. vitalii no estado do Paraná e descrever as alteraçóes clínicas, hematológicas e bioquímicas dos cães infectados. Três cães doentes da região metropolitana de Curitiba, PR, Brasil, foram submetidos a exame físico e exames laboratoriais que incluíram hematologia, bioquímica, reação em cadeia da polimerase (PCR) e sequenciamento genético. Os sinais clínicos incluíram apatia, anorexia e hemorragia. Piroplasmas intra-eritrocíticos e extracelulares foram encontrados em esfregaços de sangue periférico dos três cáes. As amostras de sangue destes animais foram positivas para Babesia sp. pela PCR baseada no gene $18 \mathrm{~S}$ rRNA. Os produtos de PCR dos três cães foram sequenciados e a análise de BLAST mostrou que as seqüências geradas por PCR eram altamente homólogas com as de $R$. vitalii previamente relatadas. Os achados hematológicos incluíram anemia grave, desvio de neutrófilos à esquerda regenerativo e trombocitopenia. Os níveis de uréia no soro aumentaram nos três cáes, e os níveis de bilirrubina direta foram elevados em um cáo.

Palavras-chave: Cáo, hemoparasita, nambiuvú, rangeliose, doença transmitida por carrapato.

Canine rangeliosis is a hemorrhagic and hemolytic disease transmitted by the ixodid tick Amblyomma aureolatum (SOARES et al., 2018). It is caused by the protozoan parasite R. vitalii belonging to the order Piroplasmida that infects erythrocytes, leukocytes

*Corresponding author: Bianca Ressetti da Silva. Laboratório de Patologia Clínica Veterinária, Universidade Federal do Paraná - UFPR, Rua dos Funcionários, 1540, Bairro Cabral, CEP 80035-050, Curitiba, PR, Brasil. e-mail: biaressetti@gmail.com and endothelial cells (LORETTI \& BARROS, 2005). In Brazil, $R$. vitalii has been reported in domestic dogs in southern and southeastern regions (GOTTLIEB et al., 2016; LEMOS et al., 2017). Few studies report the biochemical abnormalities observed in the serum of dogs infected with $R$. vitalii (COSTA et al., 2012). The present study aimed to report the molecular diagnosis of $R$. vitalii in dogs naturally infected from the metropolitan area of the city of Curitiba, state of Paraná, south Brazil, and to 
describe the clinical, hematological and biochemical findings of the infected dogs.

This study was approved by the Ethics Committee of the Federal University of Paraná (UFPR) (approval no. 035/2015). The clinical records of three male, mixed-breed dogs (dogs 1-3), presented between November 2015 and February 2016 to the Veterinary Hospital from the UFPR, were reviewed. Veterinarians performed the physical examination, and blood samples were collected $(3 \mathrm{~mL})$ by venipuncture into EDTA tubes, and into tubes without anticoagulant. A small amount of blood was sampled from the capillary beds of the ear tip for peripheral blood smears.

A Mindray BC 2800 Vet automatic hematology analyzer was used for total erythrocyte and leukocyte counts and for hemoglobin concentration measurement. The microhematocrit technique was used to obtain the hematocrit. Total plasma protein (PPT) concentration was determined by refractometry. Differential leukocyte count and screening for hemoparasites were performed on Romanovsky-stained blood smears examined by light microscopy. The tubes without anticoagulant were centrifuged at $5000 \mathrm{rpm}$ for 5 minutes to obtain serum. Biochemical parameters were determined in serum using commercial kits (Labtest ${ }^{\circ}$ ) in a Mindray BS-200 automated biochemical analyzer. Hematology and biochemistry results were interpreted based on canine reference ranges (KANEKO et al., 1997; MEINKOTH \& CLINKENBEARD, 2000).
Genomic DNA for PCR was extracted from blood samples collected in EDTA tubes via a PureLink ${ }^{\mathrm{TM}}$ Genomic DNA Mini Kit (Invitrogen ), according to the manufacturer's instructions. Primers used were BAB143-16 and BAB694-667 previously described (ALMEIDA et al., 2013), and a 551-bp fragment of the Babesia sp. 18S rRNA gene was obtained after PCR DNA amplification. PCR products were analyzed on a $1.5 \%$ agarose gel stained with GelRed and examined under UV transillumination. PCR products were sequenced by Sanger method (ABI PRISM ${ }^{\circ}$ 310 Genetic Analyser, Applied Biosystems), and the sequences obtained were submitted to BLAST analysis and compared with those in the GenBank to confirm the identity of the detected sequences.

Table 1 presents information on the three sick dogs including signalment, history, and clinical signs. One $\operatorname{dog}(\operatorname{dog} 1)$ died. The hematological abnormalities in these animals are summarized in Table 2. The main laboratory abnormalities in all three dogs were severe anemia, shift of neutrophils to the regenerative left, presence of toxic neutrophils, and thrombocytopenia. Neutrophilia was observed in two dogs (dos 1 and 2). Polychromatophilic erythrocytes were not observed. Intraerythrocytic and extracellular forms of the piroplasm were found in the peripheral blood smears of all three patients (Figure 1). Serum biochemistry results are shown in Table 3.

Table 1. Signalment, history and clinical signs in dogs naturally infected with $R$. vitalii, from Curitiba, Paraná, Brazil.

\begin{tabular}{ccccc}
\hline Dog & City & Age & History & Clinical signs \\
\hline 1 & Curitiba & 9 years & $\begin{array}{c}\text { Apathy, anorexia, } \\
\text { tick infestation }\end{array}$ & $\begin{array}{l}\text { Apathy, anorexia, dehydration, weak pulse, difficulty breathing, fever, } \\
\text { jaundice, pinnal bledding }\end{array}$ \\
2 & Sáo José dos Pinhais & 6 months & Apathy, anorexia & $\begin{array}{l}\text { Apathy, anorexia, mucosal pallor, dehydration, hematochezia, melena, } \\
\text { body condition score: thin }\end{array}$ \\
3 & Curitiba & 6 years & $\begin{array}{c}\text { Apathy, anorexia, } \\
\text { tick infestation }\end{array}$ & $\begin{array}{l}\text { Apathy, anorexia, mucosal pallor, dehydration, hematochezia, melena, } \\
\text { tachypnea, tachycardia }\end{array}$ \\
\hline
\end{tabular}

Table 2. Hematological findings and PPT levels of dogs naturally infected with $R$. vitalii, from Curitiba, Paraná, Brazil.

\begin{tabular}{|c|c|c|c|c|}
\hline & $\operatorname{Dog} 1$ & $\operatorname{Dog} 2$ & $\operatorname{Dog} 3$ & RV (adults; 3-6 months) \\
\hline Eryt. (millions/ $\mu \mathrm{L}$ ) & 2.2 & 0.7 & 1.4 & $5.5-8.5 ; 5.5-7.0$ \\
\hline $\mathrm{Hb}(\mathrm{g} / \mathrm{dL})$ & 5.1 & 1.7 & 3.3 & $12.0-18.0 ; 11.0-15.5$ \\
\hline Ht (\%) & 17 & 6 & 11 & $37-55 ; 34-40$ \\
\hline VGM & 76 & 86 & 80 & $60-77 ; 65-78$ \\
\hline CHGM & 30 & 28 & 30 & $32-36 ; 30-35$ \\
\hline Total Leuk. $(/ \mu \mathrm{L})$ & 33,700 & 34,300 & 9,400 & $6,000-17,000 ; 8,000-16,000$ \\
\hline Seg. Neut. $(/ \mu \mathrm{L})$ & 28,645 & 24,696 & 7,426 & $3,000-11,500 ; 3,700-11,100$ \\
\hline Band cells $(/ \mu \mathrm{L})$ & 2,359 & 686 & 846 & $0-300 ; 0-160$ \\
\hline Lymphocytes $(/ \mu \mathrm{L})$ & 1,685 & 8,500 & 1,128 & $1,000-4,800 ; 2,250-7,200$ \\
\hline Toxic Neutrophils & $\begin{array}{l}\text { Rare, with mild cytoplas- } \\
\text { mic basophilia }\end{array}$ & $\begin{array}{l}\text { Rare, with moderate } \\
\text { cytoplasmic basophilia }\end{array}$ & $\begin{array}{c}>30 \% \text {, with cytoplasmic } \\
\text { basophilia, cytoplasmic } \\
\text { vacuolization, toxic } \\
\text { granulation and Dohle } \\
\text { corpuscles. }\end{array}$ & Absent \\
\hline Platelets $(/ \mu \mathrm{L})$ & 180,000 & 92,000 & 48,000 & $200,000-500,000$ \\
\hline PPT (g/dL) & 5.2 & 5.8 & 5.8 & $6.0-8.0 ; 5.0-6.5$ \\
\hline
\end{tabular}

Eryt.: erythrocytes; Hb: hemoglobin; Ht: hematocrit; VGM: mean globular volume; CHGM: mean globular hemoglobin concentration; Leuk.: leukocytes; Seg.: segmented; Neut.: neutrophils; RV: reference values; PPT: total plasma protein. 
Blood samples from all three dogs were positive for Babesia sp. by PCR (ALMEIDA et al., 2013). However, sequence analysis of the PCR products showed that these were $R$. vitalii. Sequences were deposited in GenBank (Accession numbers: MG027583.1,

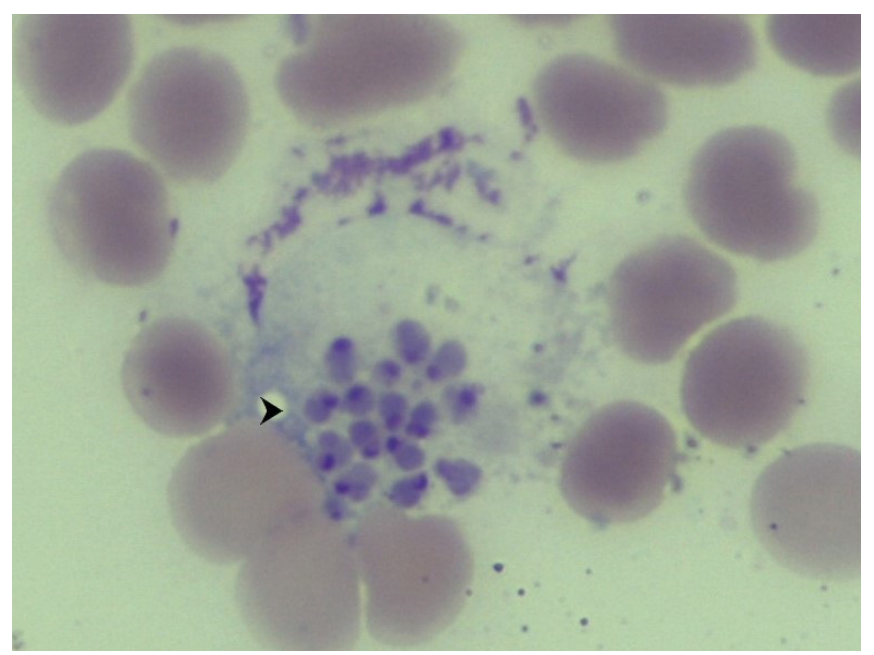

Figure 1. Photomicrograph of peripheral blood smear of $\operatorname{dog}(\operatorname{dog} 2)$ naturally infected with $R$. vitalii. Presence of extracellular piroplasms, oil immersion objective, 1000x. Romanovsky stain.
MG027584.1 and MG027585.1). The DNA sequences were compared with those from other piroplasms of dogs deposited in GenBank. Our sequences showed high degree of homology (100\% for dogs 1 and 2, and 99\% for dog 3) with those of R. vitalii reported in the State of Rio Grande do Sul, south Brazil (KT323930.1), in the State of Rio de Janeiro, southeast Brazil (KU710789.1), and in Uruguay (KP202861.1) (Figure 2).

In this study, intraerythrocytic and extracellular forms of $R$. vitalii were seen in peripheral blood smears from all three dogs. $R$. vitalii is morphologically similar to $B$. vogeli on blood smears, but genetically distinct in molecular phylogeny (LEMOS et al., 2017). In the State of Paraná, south Brazil, only one study detected $R$. vitalii in a dog by molecular diagnosis (MONGRUEL et al., 2017).

In the present report, the clinical signs observed in all three dogs included apathy, anorexia, dehydration, pale or icteric mucous membranes, and hemorrhages. These findings corroborate previous studies (LORETTI \& BARROS, 2005; FIGHERA et al., 2010; GOTTLIEB et al., 2016; FREDO et al., 2017). One dog with jaundice ( $\operatorname{dog} 1)$ succumbed to rangeliosis. Icterus is a common necropsy finding in dogs with rangeliosis (FIGHERA et al., 2010).

In canine rangeliosis, coagulation disorders affecting primary hemostasis cause a hemorrhagic disease (PAIM et al., 2012). Two dogs from our study (dogs 2 and 3) had hematochezia,

Table 3. Biochemical profile of dogs naturally infected with $R$. vitalii.

\begin{tabular}{|c|c|c|c|c|}
\hline & $\operatorname{Dog} 1$ & $\operatorname{Dog} 2$ & $\operatorname{Dog} 3$ & RV \\
\hline Urea $(\mathrm{mg} / \mathrm{dL})$ & 129.1 & 97.8 & 139.5 & $21.0-60.0$ \\
\hline Creatinine (mg/dL) & 1.2 & 0.6 & 1.3 & $0.5-1.5$ \\
\hline Alanine aminotransferase (U/L) & NP & 40.3 & 30.9 & $21.0-102.0$ \\
\hline Aspartate aminotransferase - AST (U/L) & 88.0 & NP & NP & $23.0-66.0$ \\
\hline Alkaline Phosphatase (U/L) & 133.6 & 85.4 & 83.6 & $20.0-156.0$ \\
\hline Gamma-glutamyltransferase - GGT (U/L) & 8.0 & NP & NP & $1.2-6.4$ \\
\hline Direct bilirubin $(\mathrm{mg} / \mathrm{dL})$ & 3.80 & NP & NP & $0.06-0.12$ \\
\hline Indirect bilirubin $(\mathrm{mg} / \mathrm{dL})$ & 0.10 & NP & NP & $0.04-0.40$ \\
\hline Total bilirubin (mg/dL) & 3.9 & NP & NP & $0.10-0.50$ \\
\hline Total protein - PT $(\mathrm{g} / \mathrm{dL})$ & 4.7 & 4.9 & NP & $5.4-7.1$ \\
\hline Albumin $(\mathrm{g} / \mathrm{dL})$ & 1.2 & 1.4 & NP & $2.6-3.3$ \\
\hline Globulin (mg/dL) & 3.5 & 3.5 & NP & $2.7-4.4$ \\
\hline
\end{tabular}

RV: reference values; NP: not performed.

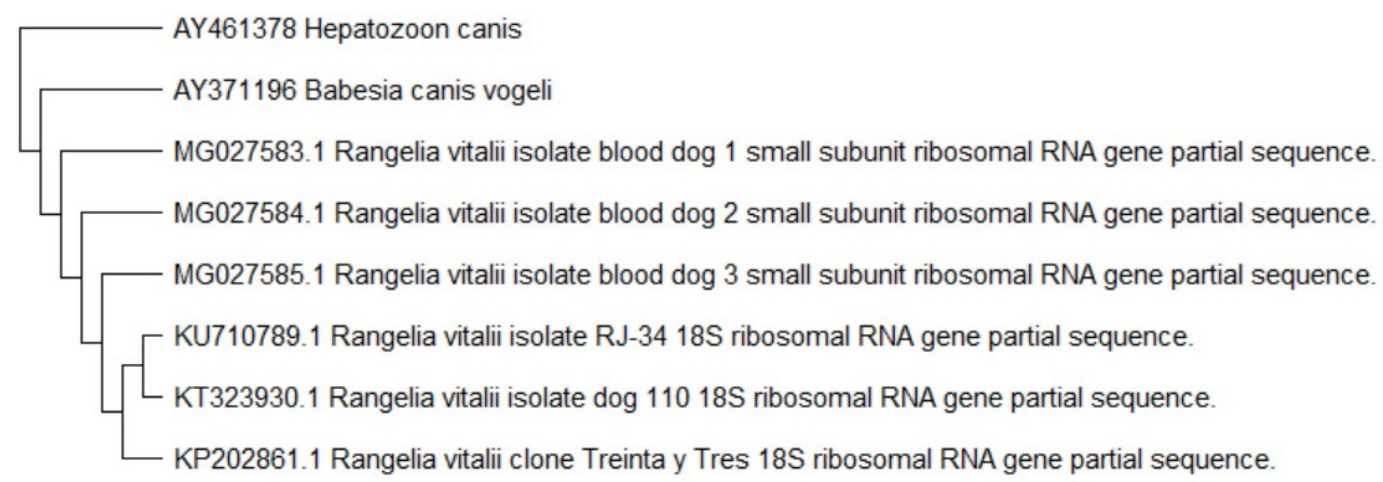

Figure 2. Distance tree (Neighbor-Joining method), conducted using MEGA software (Molecular Evolutionary Genetics For Review Only Analysis) version 6.0 (TAMURA et al., 2013). Hepatozoon canis was used as outgroup control. 
which is a clinical sign that has been observed by other authors (FIGHERA et al., 2010; FREDO et al., 2017). Hemorrhagic diathesis is a common and striking clinical presentation of cases of $R$. vitalii infection in dogs (LORETTI \& BARROS, 2005; PAIM et al., 2012). The tips of the ears from one $\operatorname{dog}(\operatorname{dog} 1)$ were bleeding when he was presented for veterinary care. Severe, bilateral pinnal hemorrhage is a typical clinical feature of canine rangeliosis, and occurs in $14.3 \%$ of the cases according to previous studies (FIGHERA et al., 2010).

Anemia and thrombocytopenia are the most common hematological findings in cases of canine rangeliosis (FIGHERA et al., 2010; PAIM et al., 2012). The absence of polychromatophilia in our study differs from previous studies where most dogs with rangeliosis presented regenerative anemia (FIGHERA et al., 2010). In our study, hematologic abnormalities included leukocytosis and neutrophilia in two dogs (dogs 1 and 2) and regenerative left shift in all three dogs. These changes in the leukogram are associated with inflammation as the inflammatory response accelerates the production and release of neutrophils from the bone marrow resulting in neutrophilia with the presence of immature neutrophils in the circulation. Increased neutropoiesis induced by inflammation results in the release of toxic neutrophils into the bloodstream (SCHULTZE, 2010). The findings of regenerative left shift in all three dogs and lymphocytosis in $\operatorname{dog} 2$ are consistent with findings from a recently published study about natural cases of canine rangeliosis (FREDO et al., 2017). In the present study, all 3 dogs were thrombocytopenic, corroborating previous studies (LORETTI \& BARROS, 2005; FIGHERA et al., 2010; FREDO et al., 2017).

Hemorrhage and anorexia are the most likely explanations for the hypoproteinemia in three dogs (TVEDTEN, 2010). We suggest that hypoalbuminemia in dogs 1 and 2 occurred due to albumin is a negative acute-phase inflammatory protein (CERON et al., 2005). Previous studies evaluating the biochemical parameters of dogs experimentally infected with $R$. vitalii didn't find any changes in the creatinine and urea serum levels (COSTA et al., 2012). In our study, there were also no abnormalities in the creatinine dosages of all three dogs with rangeliosis. However, urea levels were increased in all three dogs, most probably due to anorexia and degradation of endogenous proteins (KANEKO et al., 1997). AST and GGT enzymes, and total and direct bilirubin levels were increased in $\operatorname{dog} 1$. In this report, elevated AST levels indicate hepatic injury. Elevated GGT levels and increased serum direct bilirubin levels are indicators of cholestasis and hepatic jaundice (STOCKHAM \& SCOTT, 2011).

The present study highlights the importance of the occurrence of the canine rangeliosis in the region and the need to include it as a differential diagnosis for other hemoparasites.

\section{References}

Almeida AP, Souza TD, Marcili A, Labruna MB. Novel Ehrlichia and Hepatozoon agents infecting the crab-eating fox (Cerdocyon thous) in Southeastern Brazil. J Med Entomol 2013; 50(3): 640-646. http://dx.doi. org/10.1603/ME12272. PMid:23802461.

Ceron JJ, Eckersall PD, Martínez-Subiela S. Acute phase proteins in dogs and cats: current knowledge and future perspectives. Vet Clin Pathol 2005;
34(2): 85-99. http://dx.doi.org/10.1111/j.1939-165X.2005.tb00019.x. PMid:15902658.

Costa MM, França RT, Silva AS, Paim CB, Paim F, Amaral CH, et al. Rangelia vitalii: changes in the enzymes ALT, CK and AST during the acute phase of experimental infection in dogs. Rev Bras Parasitol Vet 2012; 21(3): 243-248. http://dx.doi.org/10.1590/S1984-29612012000300012. PMid:23070434.

Fighera RA, Souza TM, Kommers GG, Irigoyen LF, Barros CSL. Patogênese e achados clínicos, hematológicos e anatomopatológicos da infecção por Rangelia vitalli em 35 cáes (1985-2009). Pesq Vet Bras 2010; 30(11): 974-987. http://dx.doi.org/10.1590/S0100-736X2010001100012.

Fredo G, Leite-Filho RV, Pietzsch CA, Andrade CP, Duda NCB, Nascimento LC, et al. Rangeliosis: histopathological analysis, hematology and molecular detection of canine Rangelia vitalii in Rio Grande do Sul, Brazil. Cienc Rural 2017; 47(10): e20161121. http://dx.doi. org/10.1590/0103-8478cr20161121.

Gottlieb J, André MR, Soares JF, Gonçalves LR, Oliveira MT, Costa MM, et al. Rangelia vitalii, Babesia spp. and Ehrlichia spp. in dogs in Passo Fundo, state of Rio Grande do Sul, Brazil. Rev Bras Parasitol Vet 2016; 25(2): 172-178. http://dx.doi.org/10.1590/S1984-29612016041. PMid:27334817.

Kaneko JJ, Harvey JW, Bruss ML. Clinical biochemistry of domestic animals. 5th ed. New York: Academic Press; 1997.

Lemos TD, Toma HK, Assad RQ, Silva AV, Corrêa RGB, Almosny NRP. Clinical and hematological evaluation of Rangelia vitalii-naturally infected dogs in southeastern Brazil. Rev Bras Parasitol Vet 2017; 26(3): 307-313. http://dx.doi.org/10.1590/s1984-29612017040. PMid:28902259.

Loretti AP, Barros SS. Hemorrhagic disease in dogs infected with an unclassified intraendothelial piroplasm in southern Brazil. Vet Parasitol 2005; 134(3-4): 193-213. http://dx.doi.org/10.1016/j.vetpar.2005.07.011. PMid:16153781.

Meinkoth JH, Clinkenbeard KD. Normal hematology of the dog. In: Feldman BF, Zinkl JG, Jain NC. Schalm's veterinary hematology. 5th ed. Philadelphia: Williams \& Wilkins, 2000. p. 1057-1063.

Mongruel ACB, Sousa MG, Valente JDM, Barbosa IC, Spanhol VC, Sezyshta A, et al. First report of Rangelia vitalii in a dog from Paraná State, Southern Brazil. Arch Vet Sci 2017; 22(4): 139-144. http://dx.doi. org/10.5380/avs.v22i4.56936.

Paim CB, Paim FC, Silva AS, França RT, Costa MM, Leal CAM, et al. Trombocytopenia and platelet activity in dogs experimentally infected with Rangelia vitalli. Vet Parasitol 2012; 185(2-4): 131-137. http://dx.doi. org/10.1016/j.vetpar.2011.09.039. PMid:22019200.

Schultze AE. Interpretation of canine leukocyte responses. In: Weiss DJ, Wardrop KJ. Schalm's veterinary hematology. Gth ed. Iowa: Blackwell Publishing; 2010. p. 321-334.

Soares JF, Costa FB, Girotto-Soares A, Silva AS, França RT, Taniwaki SA, et al. Evaluation of the vector competence of six ixodid tick species for Rangelia vitalii (Apicomplexa, Piroplasmorida), the agent of canine rangeliosis. Ticks Tick Borne Dis 2018; 9(5): 1221-1234. http://dx.doi. org/10.1016/j.ttbdis.2018.05.004. PMid:29752143.

Stockham SL, Scott MA. Fundamentos de patologia clinica veterinária. 2nd ed. Rio de Janeiro: Guanabara Koogan; 2011.

Tamura K, Stecher G, Peterson D, Filipski A, Kumar S. MEGA6: molecular evolutionary genetics analysis version 6.0. Mol Biol Evol 2013; 30(12): 2725-2729. http://dx.doi.org/10.1093/molbev/mst197. PMid:24132122.

Tvedten H. Laboratory and clinical diagnosis of anemia. In: Weiss DJ, Wardrop KJ. Schalm's veterinary hematology. 6th ed. Iowa: Blackwell Publishing; 2010. p. 152-161. 